\title{
Black Muslim Women's Use of Spirituality and Religion as Domestic Violence Coping Strategies
}

\author{
Olubunmi Basirat Oyewuwo, PhD, LMSW \\ Northeastern Illinois University \\ o-oyewuwogassikia@neiu.edu
}

Abstract

\begin{abstract}
Women use multiple strategies to cope with domestic violence, including religion and spirituality. While there is a body of research on domestic violence in the American Muslim community, little exists on the domestic violence experiences of a large concentration of Muslims in the United States - Black women. This article reports findings of a small-scale qualitative study that examined Black Muslim women's use of religion and spirituality to cope with domestic violence. Five themes emerged: seeking help from religious leaders, prayer, using Quranic wisdom, spiritual cleansing, and connecting to a larger purpose. Implications for practice and future research are discussed.
\end{abstract}

Keywords: Domestic violence, coping, Black Muslims, religion \& spirituality

\section{Introduction}

Domestic violence impacts the lives of millions, and according the Centers for Disease Control (CDC), someone experiences physical abuse at the hands of an intimate partner every 20 minutes (2014). In the United States, 30 percent of women have experienced rape, physical violence, or stalking by an intimate partner (Black et al., 2011). Scholars have documented how women cope with the violence they experience, examining factors that influence coping strategies, the types of coping strategies, and the outcomes of such strategies (Waldrop \& Resick, 2004; Goodman, Smyth, Borges, \& Singer, 2009; Lindhorst, Nurius, \& 
Macy, 2005; Mitchell, Hargrove, Collins, Thompson, Reddick, \& Kaslow, 2006). Women cope with domestic violence in a variety of ways including placation, resistance, safety planning, formal and informal networks, or legal remedies (Goodman, Dutton, Weinfurt, \& Cook, 2003). In addition, some women use religion and spirituality to cope, and studies have examined the role of religion and spirituality in the lives of women experiencing domestic violence (Fowler, Faulkner, Learman, \& Runnels, 2011; Hassouneh-Phillips, 2003; Watlington, \& Murphy, 2006). The purpose of this article is explore how women use religion and spirituality to cope with domestic violence by focusing on the experiences of an understudied group - Black Muslim women.

\section{Domestic Violence and American Muslims}

A 1999 study on domestic violence in the American Muslim community conducted by Sharifa Al-Khateeb found that domestic violence occurred in 10 percent of homes, but the researcher believed that this number was grossly underestimated. A handful of studies since have attempted to capture domestic violence prevalence rates in the American Muslim community. For example, Adam and Schewe (2007) identified that, in their sample of Hindu and Muslim South Asian women, 73 percent $(n=41)$ of the Muslim women were victims of domestic abuse. While that research studied a specific ethnic group and used nonrandom sampling, such studies highlight the need for further investigation of domestic violence in the American Muslim community.

Spirituality and religion can serve as important means for dealing with domestic violence across faiths and religious groups (Yick, 2008), and knowledge of religious groups and how faith and spirituality shape their experiences with domestic violence is key to building a culturally sensitive and responsive practices. Several studies have indicated that Black women and Muslim women who experience domestic violence use spirituality and religion to cope (Akinsulure-Smith, Chu, Keatly, \& Rasmussen, 2013; Fowler, Faulkner, Learman, \& Runnels, 2011; Hassouneh-Phillips, 2003; Hodges \& Cabanilla, 2011; Nash, 2005; Potter, 2007). However, studies of bBlack women often include a majority-Christian sample. While there is a body of research on American Muslim women's experiences of domestic violence, few studies have focused on Black Muslim women in their sample; this research gap is made more significant by the fact that Black Muslims comprise a large racial group among American Muslims (Younis, 2009). To fully address the needs of women experiencing violence, research should include the diversity of women, and "the intersection of culture and religion, socioeconomic status, political history, and a history of patriarchal oppression related to cultural practices of family violence in particular, needs further study by Muslims" (Alkhateeb \& Abugideiri, 2007, p. 21). 


\section{Religion, spirituality, and domestic violence coping}

Previous examinations of religion related to this study have correlated women's levels of spirituality and religiosity with psychological or social outcomes, or in comparison between samples of abuse victims and women who have not experienced abuse (Finn, 1985; Mitchell, Hargrove, Collins, Thompson, Reddick, \& Kaslow, 2006; Watlington \& Murphy, 2006). There are conflicting findings on levels of spirituality and religion among women who have experienced domestic violence. A 1985 study found that women who experienced abuse reported less attachment to spirituality than those who had not (Finn, 1985). Mitchell and colleagues (2006) reported similar findings in a study of low-income African American women, identifying that participants who had experienced abuse had lower levels of spirituality than those who had not. However, a later study found that $97 \%$ of a racially diverse sample of women who had experience domestic violence identified spirituality as a source of strength (Gillum, Sullivan, \& Bybee, 2006). These differences could be due to variable ways of measuring religion and spirituality or to differences in overall study design.

Other studies have similarly found religious and spiritual coping strategies among victims of domestic violence. In a qualitative study exploring the use of religion and spirituality among an ethnically diverse group of Muslim women, participants reported using religion to cope with domestic violence. Muslim women reported coping by listening to Quranic recitation, praying, and meditation through repeating Quranic verses or other Islamic phrases (HassounehPhillips, 2003). Other studies have reported similar religious coping strategies among non-Muslim African and Haitian immigrant women (Latta \& Goodman, 2005; Ting, 2010). Researchers have also examined how religious views and interpretation of religious text influence women's responses to domestic violence, as well as how women use religion and spirituality as a response to abuse. In a study of Christian African American wives who experienced domestic violence, participants reported that their faith provided them with a sense of agency during the relationship (Nash, 2005). Women also reported using faith practices such as prayer and religious interpretation both as a means of managing the abuse and as a way of identifying strategies to end the abuse.

In a literature review of facilitators and barriers to domestic violence service seeking among American Muslim survivors of domestic abuse, OyewuwoGassikia (2016) found that religious perceptions of abuse served to both facilitate and hinder seeking services. Potter (2007) found that African American women used religion and spirituality to assist them in leaving their violent relationships. One Muslim participant in the same study described that when she reported the abuse to her religious community, men of the community came to her home and escorted her husband away. Another Muslim participant reported being told on her wedding day that if there were any problems in the home, she should call other community members to intervene. Even 
when religious institutional support is not available, women have expressed the belief that they, the institutions, should assist domestic violence victims (Gillum, 2008). In a study of Arab Muslim women, religion was cited as a barrier to seeking help for domestic violence, and 43 percent of participants reported their religion as being a barrier to seeking help outside of the relationship (Abu-Ras, 2003). Fowler and colleagues (2011) found in their qualitative study of a diverse group that women who reported high levels of spirituality were more likely to use faith services over domestic violence shelters. However, those with higher instances of abuse were more likely to report dissatisfaction with faith-based services.

Watlington and Murphy (2006) investigated spirituality, religious involvement, religious coping, and social support as correlates of post-traumatic stress disorder (PTSD) for African American survivors of domestic violence. They identified that participants who scored higher on spirituality and religious involvement reported fewer symptoms of depression than their counterparts did, and religious involvement was negatively associated with PTSD. However, Watlington and Murphy indicated that the direction of the relationship is unclear; whether religion and spirituality affected mental health or mental health affected their religious involvement could not be determined. Relatedly, Gillum and colleagues (2006) found that domestic violence victims who were involved in religious institutions and viewed spirituality as a source of comfort and support had less depression and a higher quality of life. The study demonstrated that religious involvement was related to increased social support for women of color, with social support being a factor related to better psychological wellbeing (Gillum et al., 2006).

The present study uses qualitative methodology to examine how Black Muslim women utilize religion and spirituality to cope with domestic violence. This study's methods examine how gender, race, and religious identity -- and intersectionality of these constructs -- influence Black Muslim women's responses to domestic violence.

\section{Theoretical Framework: Coping}

This study applies the coping theory in the examination of how Black Muslim women respond to domestic violence. Coping is concerned with how people manage stressful events and the decisions a person makes and what influences their decision-making when a situation has exceeded their capacity. (Folkman, Lazarus, Dunkel-Schetter, DeLongis, \& Gruen, 1986; Lazarus, 1993; Lazarus \& Folkman, 1984). Coping has been applied to investigating and understanding women's responses to domestic violence (Lindhorst, Nurius, \& Macy, 2005; Hamby \& Gray-Little, 1997; Goodman, Dutton, Weinfurt, \& Cook, 2003). 
Two processes that mediate stressful events and their outcomes are at the center of the framework, cognitive appraisal and coping. The first process, cognitive appraisal (Lazarus, 1998; Lazarus \& Folkman, 1984; Folkman et al., 1986), is made up of primary and secondary appraisal. In primary appraisal, "the person evaluates whether ... she has something at stake in the encounter" (Folkman et al., 1986, p. 993) and if the situation is significant to her wellbeing (Lazarus, 1998). If she finds in the primary appraisal process that something is at stake, and the response is that she is in harm's way, she then undergoes secondary appraisal (Folkman et al., 1986; Lazarus, 1998). In secondary appraisal, she discerns if she can do anything to prevent harm, overcome the situation, or change the situation. This is the stage in which a person decides how to react, whether cognitively or behaviorally. This reaction can be conscious and deliberate or unconscious and automatic (Lazarus, 1998). She evaluates her options and the primary and secondary appraisals come together to determine if the situation is significant for her wellbeing and if it is threatening or challenging (Folkman et al., 1986).

The second process of coping theory is coping. Coping "refers to the person's cognitive and behavioral efforts to manage (reduce, minimize, master, or tolerate) the stressor" (Folkman et al., 1986, p. 572). At the end of the process of coping there is an immediate outcome, the extent to which the stressful situation was resolved successfully as assessed by the person experiencing the stress. This assessment is based on the individual's values, goals, and expectations concerning the situation (Folkman et al., 1986).

Coping is not concerned with "the best" methods; coping examines how to manage stress, not how to master stress (Lazarus \& Folkman, 1984). Although one may cope by attempting to master their environment, all forms of dealing with the stressful situation - whether seemingly passive (such as denial) or aggressive (such as a violent, physical response)—may be considered coping.

\section{Methods}

\section{Recruitment}

After obtaining approval from the University of Illinois at Chicago Institutional Review Board, participants were recruited from community sites throughout Chicago, including mosques, community events, and snowball sampling. To be included in the study, potential participants had to meet the following inclusion criteria: (1) self-identifying as having experienced domestic violence in an intimate partner relationship as an adult (over 18); (2) self-identifying as a woman; (3) belonging to a racially Black ethnic group or self-identifying as Black (4) self-identifying as Muslim; (5) self-identifying as Muslim at the time 
of the abusive relationship; (6) willingness to discuss past abuse; (7) speak English; and (8) self-identifying as a survivor of abuse.

Study procedures included an initial interview exploring their experiences and responses to domestic violence and a follow-up interview to clarify ideas expressed in the initial interview and to allow participants to provide more detail and depth about information that was particularly relevant to the study.

\section{Sample}

Six women enrolled in the study. All participants completed an initial interview, and 5 completed a follow-up interview, with a total of 11 interviews completed. Interviews ranged in length from 23 minutes to almost two hours. Three participants completed individual member check interviews. During the member check, I shared study findings with each participant and each expressed agreement with study themes and conclusions. Thus, I made no changes to analyses or conclusions after completing the member check interviews. Table 1 provides a description of the sample.

There are several mosques in the Chicago, and many mosques have an ethnic or nationality predominant representation. For this reason, and due to the small sample size, I do not disclose the West African participants' countries of origin, reducing the likelihood of their being identified by fellow community members.

Analysis. Interviews were recorded, transcribed verbatim, and stripped of identifying information. I created memos throughout data collection and analysis, making notes of possible thematic and analytic significances.

Table 1. Sample Characteristics

\begin{tabular}{|c|c|c|c|c|c|c|}
\hline Pseudonym & Ethnicity & $\begin{array}{l}\text { Children } \\
\text { (Yes/No) }\end{array}$ & $\begin{array}{l}\text { Convert } \\
\text { (Yes/No) }\end{array}$ & $\begin{array}{c}\text { Number of } \\
\text { Physically } \\
\text { Abusive } \\
\text { Relationships }\end{array}$ & $\begin{array}{l}\text { Interviews } \\
\text { completed }\end{array}$ & $\begin{array}{c}\text { Member } \\
\text { check }\end{array}$ \\
\hline Asiyah & West African & No & No & 1 & 2 & Yes \\
\hline Jamilah & $\begin{array}{l}\text { African } \\
\text { American }\end{array}$ & Yes & Yes & 1 & 1 & \\
\hline Latifah & West African & Yes & No & 1 & 2 & \\
\hline Naila & $\begin{array}{l}\text { African } \\
\text { American }\end{array}$ & Yes & Yes & $>1$ & 2 & Yes \\
\hline Rashida & $\begin{array}{l}\text { African } \\
\text { American }\end{array}$ & Yes & No & 1 & 2 & Yes \\
\hline \multirow[t]{2}{*}{ Rawhiya } & $\begin{array}{l}\text { African } \\
\text { American }\end{array}$ & Yes & Yes & $>1$ & 2 & \\
\hline & & & & & $\begin{array}{c}\text { Total } \\
\text { interviews: } \\
11\end{array}$ & \\
\hline
\end{tabular}


The study was analyzed utilizing grounded theory methodology (Charmaz, 2006; Oktay, 2012). I began by open coding data transcripts line by line and stopped code development when I reached saturation, "when no new issues [were] identified in the data" (Hennink, Hutter, \& Bailey, 2011, p. 217). I began to see repetition in codes after the second participant. I then coded subsequent transcripts line-by-line, using codes from the codebook as my guide. After initial coding, I removed repetitive codes and collapsed redundant codes. After refining this into an initial code list, the codes were grouped into concepts, narrowing the $200+$ codes to 27 . The codes were then grouped further into 6 major categories. To determine the sample's religious and spiritual coping, I examined the codes under the major category "domestic violence responses" and compared cases to identify women's motivations for using religion and spirituality, how they used it, and its outcomes. The use of religion and spirituality were categorized as being help-seeking strategies.

While grouped together as spiritual/religious coping strategies, I differentiated between "spiritual" and "religious" coping strategies. Spiritual coping strategies were those in which women used intangible supports, such as seeking help from Allah (God) through prayer. Religious coping strategies were defined as seeking help from religious leaders, and four of the five women who reported using religion and/or spirituality sought this form of help. An appendix is included that defines the Arabic terms used by study participants to express aspects related to their religion and spirituality.

Theoretical sensitivity. A key component of qualitative research is positioning one's self in relation to the study. Therefore, it is necessary for me to disclose my professional and personal motivations for why and how I chose to conduct this research.

I am a social worker with experience working both in a shelter with survivors of domestic violence and in a battering intervention and prevention program with perpetrators of abuse. I am also a middle-class heterosexual ablebodied Black Nigerian American Muslim woman who was born and raised in the United States. When I speak of "my" community in everyday life, I may be referring to any of the following: the American Muslim community, the Nigerian community, the African community, the Black community, or the Nigerian Muslim community. I may also be referring to my neighborhood, the city I grew up in, or the city where I currently live. I am actively involved in the American Muslim community broadly; while my primary affiliation has been with predominately Nigerian mosques, I engage and volunteer with Muslim communities of various ethnic and cultural backgrounds.

Ultimately, my professional and personal experiences shaped the research questions I asked and the theoretical frameworks I used to examine the domestic violence experiences of Black Muslim women. Additionally, my community membership and involvement influenced how I approached recruitment. For 
example, I did not want to place a woman at risk of further abuse or have women I interacted with be perceived as having experienced domestic violence. As a result, I limited the knowledge of my study by recruiting in women-only settings and distributing information cards as opposed to displaying recruitment flyers. I was also cautious of not directly asking women I knew to have had experienced domestic violence to participate in the study. While this limited my recruitment, I chose this strategy because I was concerned that, given my community membership, my doing so would be coercive. All participants enrolled in the study based on the recruitment methods I describe in earlier sections.

\section{Results}

Five themes emerged that revealed how participants utilized religion and spirituality to cope: seeking help from religious leaders, prayer, using Qur'anic wisdom, spiritual cleansing, and connecting to a larger purpose. I categorized seeking help from religious leaders as a religious coping strategy, and the four remaining themes as spiritual strategies.

\section{Seeking Help from Religious Leaders}

One way in which women coped with domestic violence was to seek help and guidance from religious leaders. For example, Rashida described seeking an imam's help to facilitate discussion between her and her husband. She explained, "I told the imam the situation and told the imam to tell [my husband] that I wanted to speak with him after jumah with the imam." Naila also sought this form of help. However, Naila explained that she sought help from a different mosque from the one she had frequented. This was due to isolation, with few people she could talk to about the abuse due to her husband spreading false rumors about her. Thus she described, "I started going to a different masjid for jumah.... And the imam ... I was able to talk to him, explain to him ... 'This is what's happening." Naila found support in the imam; "[The imam] said, "Okay, you've got a refuge here. And you need money, we're going to get money together for you and you're cool." However, her attending the new mosque was not without question from community members. She explained, "[People asked] 'Why are you here?' I was just, you know, covering, privacy. 'I'm in the neighborhood and that's why I'm here now." Naila cautiously navigated the new context by not revealing to community members why she was attending the new mosque.

Latifah described enlisting the African Muslim community to help with the abuse in her marriage. She explained, "you know the African people, they come in? The imam ... they come in my house." She found the religious com- 
munity willing to help, and the imam told her husband to stop abusing her. She cited the imam's intervention when her husband justified his abuse by accusing her of having an extramarital affair:

You know, the African people, if you got a something, they come in my house to tell him. Like, [the imam] ask my husband "What happened? You never see any boyfriend?" He say, "I never see any boyfriend. But I just jealous." The imam says, "Stop [doing] that. ... You don't need to do that. If you don't like it just divorce. You don't know. You don't need to do like this."

While religious leaders instructed her husband to stop abusing her, they also advised her to stay in the relationship. Latifah explained, "[They told me] "just stay [with your] your husband. Don't listen to anybody. Don't look at anybody. Just look at your children." One day, he kill me, who gonna take care of my children? So I can't do that." Latifah's experience reflected one mixed outcome of using religious leaders - while intervention curbed the abuse, it also risked putting Latifah in danger by suggesting she stay in the abusive marriage because of her children. As she asserted, if she were to die, her children would be at a greater risk, so she ultimately went against the advice given and left the relationship.

Asiya also received mixed responses from religious leaders. While she encountered some religious leaders who supported her in leaving the relationship, she also reported feeling unsupported by some of the religious leaders she sought advice from at the end of her marriage. She was encouraged to return to the abusive relationship and have patience, "sabr":

So many imams were telling me, "go back and be patient." I'm like, do you unders- you guys preach sabr, but it's like you do not understand the tafseer of sabr! Sabr is not you slap me and I wait 'til you come back and slap the second. Sabr is, you slap me and I say "Qadr of Allah that you will slap me". That second one - no way. I remove myself from that aggravating situation. That is what I understand as sabr. This is not patience. Telling me to stay- if my husband has a little shortcoming, it's patience but I have to deal with. ... But abusive - I lost like over 20 pounds.

Jamilah did not seek help from religious leaders, and her experience highlight barriers to this form of coping. Jamilah identified fear as one reason she did not talk to an imam about the abuse:

Well, I would have imagined that I could have went to the masjid and spoke with the imam, but I didn't. And I think I didn't because probably why most Muslim women don't, is exposing the Muslim brother. Exposing a Muslim man, exposing his image. 
You know, someone that comes to the masjid for dua and prays, is active in this community, who other people think would never be this other person behind closed doors. So I think the woman takes on a certain amount of responsibility of not exposing the faults of the man that's abusing them.... And you're steady, making excuses and being the doormat, because you're the one that's being abused. By not exposing him, it's going to continue. You're not even allowing yourself the avenue to stop it. Because you're not exposing it, you're just keeping it hidden for fear. And here again is fear. "Well, I'm going to have to go back home if I tell, and what will he do if I go to the imam and tell? He might hit me harder next time or hurt me." .... You're afraid for your life. You're afraid. You don't know what's going to happen. You don't know to what extent. You know, when someone gets angry, you don't know how much rage is there. And will they kill you? You don't know. And while you're going through that, your life is this danger. It's just a dangerous type of situation.

As Jamilah describes, fear - both of tainting her husband's image and of increased abuse - was a factor in her not seeking help from a religious leader. As she explains, the complexity of not "exposing the Muslim brother" and attempting to keep oneself safe -- by not reporting the abuse, that the silence allows the abuse to continue; thus, women in domestic violence relationships are in a life-threatening situation having to navigate risk with no certainty of a good solution.

\section{Spiritual coping strategies}

Participants reported utilizing spirituality broadly, including praying, seeking and utilizing Quranic wisdom, engaging in spiritual cleansing, and to help with moving on.

Prayer. Prayer was one way in which participants engaged spirituality to cope with the abuse, for support and guidance. Asiya described praying when she first realized there were problems in her marriage:

I just started praying. I - again, I didn't recognize that it was abuse. I just knew that this was wrong. I knew that one, this is not what I want. And two, by at least basic marriage standards this doesn't seem right, you know? That even if I wanted something extravagant, someone so passionate, so romantic, at least there is a basal level that should be in marriage, especially a new marriage.

Asiya's beliefs about what a new marriage is supposed to look like led her decision to pray for guidance. She further described how she sought guidance in prayer, initially seeking help to fix the relationship: 
I just prayed and cried and cried and cried, and I kept telling God like "something is wrong, I don't know, but something is wrong. Help me change it, teach me what to do, how I can be better, how I can please [my husband]."

Later in the relationship, Asiya prayed for guidance in her decision as to whether or not she should leave the relationship:

And, I said okay "God like, just let's make this a sign, let's make a deal. If I get pregnant this month, okay, I will take it that I'm supposed to be here. And I will work it out somehow. But if I don't, I'm done." And . . . once ... . I realized I wasn't pregnant, I was like okay. . . . I started just researching what can I do.

Asiya's process of leaving was facilitated by her deep belief in Allah's will and belief that she would receive signs as to what she should do.

Prayer played a critical role in every stage of Asiya's experience of domestic violence, from the recognition of problems in the marriage, to seeking help from others, to leaving the abusive relationship. Asiyas response when asked what advice she would give others experiencing domestic violence:

The first thing I would say is talk to God. And talk to God first. First, because for me, I think that was what I did first and He guided me to- because I could have spoken to just anybody. I could have spoken to people who would force me to stay or give me wrong advice. But I think like the first few people I spoke with were pivotal.

Using Qur'anic wisdom. Women reported reading Qur'an and religious text to cope with abuse, and these strategies provided them with strength to persevere. Naila described how she would receive guidance from Qur'an, "so I just kept reading [the Quran].... Allah was, like, giving me guidance in ... Quran. Things like, 'Those with patience persevere." Naila also began to see signs from Allah as a way and means to eventually leave the relationship:

So I'd go to Qur'an and I'd read Qur'an, and these different [ayat] would come up. Allah giving me signs. "Be patient. You're going to, you know, you're going to elevate out of it, you know. Things are changing and the strength of, and being prepared for." I'm like, "Okay, this is it. I totally am submitting to that. I'm being patient. I'm preparing. And things are going to change, and I'm getting out..."

Rawhiya described how her invoking God and reflecting on Qur'an cause her to react in a way that potentially saved her life. She explained one violent incident: 
[My husband] grabbed me by my neck. I thought he was going to try to strangle me to death. I remember telling him, "In Allah's name, let me go!" And then, in my mind, I started thinking about that story in the Quran and also in the Bible, before I became a Muslim, about Cain and Abel, and about Cain killing his brother Abel. So I said to myself, well, if that's the way to be, then so be it. That's what I said.

Rawhiya's invocation of God had the effect of pacifying her husband; he stopped strangling her and left the home. She further described, "He started kind of loosening his hand and then just ... like that, dropped it. So it seemed like he was kind of reflecting upon what I was saying. That's the impression I got, my interpretation."

Rawhiya was greatly influenced by her knowledge of religious text. When explaining why she invoked God when her husband was strangling her, she stated "I felt helpless and there was no way that I could protect myself." She went on to explain how her knowledge of Islam brought her comfort during that abusive incident:

But in essence, I was thinking about with Abel. ... And the murder, the blood, would be on his hands. That's what I'm thinking, okay, I'll be off the hook. That's what I'm thinking. But you won't. It'll be you and Allah to deal with.... I was scared at first. But then, when I started thinking about Cain and Abel. That made me feel more calm and peaceful. [I thought] "Okay, I may not be here but if not, then it's all in Allah's hands. I'll just leave it at that." So I believe that the religion is what helped me be so peaceful and knowing what was in Qur'an, I was grateful. That was, that helped keep me calm.

Spiritual cleansing. All women in the study are Muslim, and each found different ways of using spiritual components of religion to cope with domestic violence. Most of the ways appear inherently "Islamic" such as reading the Quran or prayer. Latifah, however, described a strategy that is not specific to Islamic practice - taking a special bath to cleanse herself from the harms of voodoo:

That's the voodoo.... [So] I bring the stuff to take a shower, then maybe [the voodoo] [will go away]. When I bring something to take shower, maybe that [voodoo] going to go [away a] little bit.

Specifically, Latifah used a spiritual cleanse to protect herself after learning her husband sought out voodoo to harm her and her children: 
Yeah, I call the people who tell me that [my former husband] do the voodoo a lot of times. They told me my husband doing something for my son. That night time my son fine, and [then] he [became] sick, [and] we go to the hospital. ... [My son] don't die right now but I need to be careful for that ... I don't call [my former husband]. I don't care. And maybe that's why. He told me, he say, "Why you say you don't like me? You need to come back again.... I'm going to keep doing voodoo [until] you come home one day. You don't marry anybody."

Latifah, who also reported seeking the imam's help in other abusive incidents through the marriage, described why she did not seek the imam's help for her husband's use of voodoo against her. She explained, "No. I don't tell [the imam], because they don't believe it. You know, they Muslim, they don't believe ... [in] voodoo.... Because they're Muslim. They think you're supposed to trust ... God." Voodoo was a very real form of abuse that caused Latifah to fear for her and her children's safety, yet she knew that this form of abuse may not be perceived as being risky or having a real effect by religious leaders. Thus, Latifah sought a different form of spiritual help to cope.

Connecting to a larger purpose. Despite the violence they experienced, participants connected their experience of abuse to having a larger meaning and purpose in their lives. For example, in her second interview, Rawhiya noted that she had shared more than she anticipated she would in the first interview. She concluded, "Well, I guess I said what Allah made me say, so it's okay." She further explained that she viewed speaking to me as a way to help others, thus providing a deeper meaning to the experience. She noted, "A lot of things I did say ... perhaps could help other people. If somebody have problems with abuse. That was the main thing that felt good to me, to share it so that perhaps ... it helps give more insight."

Asiya described how she has given advice to other women who are going through domestic violence, encouraging them to engage in spiritual means of coping to overcome:

I have a friend who's actually going through it. She's not a Muslim, but she's African, she's Christian. And I told her I said, 'girl, the way Jonah was crying in the belly of the whale and the heavens already knew his voice, so when he was in trouble they knew that familiar voice and He knew something was wrong.' I said, 'make yourself so beloved to God that whoever is at war with you is at war with God'. . . So, the first advice I would tell someone is just stick to God. . . . No matter how horrible, horrible, horrible it looks it always gets better. .. It gets better, ease will come. So, and it's God that gives that and it's faith that takes you there. So you know just believe in God, and pray. Talk to God and listen. 
Rashida expressed her belief "that our lives really are not about us. You know what happened to me happened to me to perfect me as a tool for Allah." For Rashida, her experience allows her to help and educate others:

With any ... painful life experience I think that there's a good ending. And I think for me that helps me to be healthy, even though I experienced something that was unhealthy. . . I know that the good in it is this - that maybe my experience can help somebody else..... I tried to not really dwell on the fact that this happened in my life, but that I'm going to focus on the good that can come from that.

Rashida's helping others is connected to her journey of healing, what she calls her jihad, or spiritual struggle. She stated, "I . . . don't think I'm healed, I think that it's a journey, and ... I think this is part of my jihad. And I don't necessarily think [I'm going to] ever be healed . . . but I'm trying to not have my power taken from me."

\section{Discussion}

Participants in this study used religion and spirituality in a variety of ways to cope with the domestic violence they faced, including seeking the help of religious leaders, praying, reading Qur'an, spiritual cleansing, and connecting their experience with a higher purpose. Through examining the motivations for participants' responses, their cognitive appraisal considerations emerged. They were motivated to use and not use religion and spirituality for a variety of reasons, one of which included fear. For some women, fear led them to seek help from a religious leader, and for others, fear prevented them from seeking this form of help. The use of spiritual strategies served to provide participants with strength, guidance, calm, and motivation to leave the abusive relationships. However, use of religious leaders produced mixed outcomes- some women reported being supported in their leaving, while others were encouraged to stay or return to the relationship.

Another study on American Muslim women's use of religion and spirituality as domestic violence coping strategy identified that spiritual practices, such as prayer and reading Qur'an, serve as a source of strength for women in abusive relationships; however, such practices did not necessarily lead to women leaving the abusive relationship (Hassouneh-Phillips, 2003). In contrast, one participant in the present study identified that it was her prayers that led her to leaving the relationship. Potter (2007) found that in her sample of Black Christian and Muslim women, participants used spirituality to "get through and get out of the abusive relationships" (p.271). Similarly, women in this study 
reported that spiritual coping brought them comfort, and even helped them to leave the relationship.

Participants found success through faith leaders, while others did not. Interestingly, this contradiction is also present in the current literature. Potter (2007) identified that Christian study participants reported a lack of support whereas Muslim study participants reported feeling supported by their religious community. However, Hassouneh-Phillips (2001a) identified that women faced barriers, such as disapproval from the community, when leaving their relationships. It is likely that religious support for domestic violence, or lack thereof, is due to one's knowledge of domestic violence and its effects. In a recent study on the outcomes of training Seventh-Day Adventist clergy on responding effectively to domestic violence, researchers found that clergy displayed increased knowledge of domestic violence "resources and services, decreases in misunderstandings about abuse dynamics in intimate relationships, and growth in pastors' abilities and motivations to be proactive in addressing spouse abuse in their congregations" (Drumm et al., 2017, p. 12). Thus, one's knowledge and awareness of domestic violence shapes their competence in addressing it.

\section{Study Limitations and Strengths}

I faced challenges with recruitment, likely due to my recruitment methods and the sensitive nature of the research topic. The initial goal for the study was to recruit a minimum of ten participants, but it took a calendar year to recruit six, with most participants being recruited around the holy month of Ramadan when Muslims more often attend the mosque.

There is ideological diversity in Islam in the form of various sects. One limitation of this study was that all study participants could be categorized as "Sunni" Muslim. As with group classifications, there is diversity within the Sunni sect. However, the study lacked discernable ideological diversity due to all participants belonging to the same sect. In addition, while the study did capture some ethnic diversity, the sample was not representative of the ethnic diversity of Black Muslim women. For example, East African women are a significant population of Black American Muslims not included in the sample.

Despite the limitations, there were notable strengths. I employed a number of strategies to ensure the trustworthiness, authenticity, and quality of the study. One such strategy was member checking, a technique that is used to enhance the trustworthiness of qualitative studies (Charmaz, 2006; Oktay, 2012). After completing data analysis, I shared major findings with three participants, two of whom identified as African American and one who identified as West African, to get their feedback on how well the findings reflected their experiences (Charmaz, 2006). 
I also engaged in memo writing throughout data collection and analysis. A form of bracketing (Auerbach \& Silverstein, 2003; Tufford \& Newman, 2012), this strategy helped me to note insights and hunches that later informed my core categories. This strategy was particularly useful during open coding when I wanted to focus on developing substantive codes - when I came across ideas that were theoretical in nature, I created a memo and revisited the memo in later stages of data analysis.

Another concern of the quality of qualitative research is that of its transferability (Miles et al., 2014). I employed two strategies to ensure transferability: theoretical sampling and connecting my findings to existing theories. In addition to maintaining a code book (Hennink et al., 2011), I also kept a record of changes I made to codes after categories were established.

As an insider to the community in which I recruited participants, it was necessary that I bracketed my own biases and assumptions when analyzing data and making conclusions about the findings. I sought advice from "community consultants" - those who have insight into the culture and religious beliefs of the participants - as a way for me to maintain some level of objectivity as opposed to me assuming what participants intended. For example, when I came across the use of voodoo, I consulted with members of the West African Muslim community about how to interpret this concept. I did not provide consultants with access to the data or details of specific participants; rather I asked about concepts for which I needed further clarification.

\section{Implications and Conclusions}

Findings from this study have implications for practice. Practitioners should be abreast to the variety of ways women in domestic violence situations seek help to stay safe, even before they encounter professionals in formal agency settings. Participants in this study used religious and spiritual coping strategies-along with other strategies - to keep themselves safe and well. It may be that even when a woman seeks out social services or other domestic violence services, her religious community and spiritual coping mechanisms are also significant in helping her heal from violence. Importantly, women do not necessarily leave this coping strategy behind when they seek help through formal services; professionals have the ability to facilitate religious and spiritual coping for clients who would like this form of help. For example, women may benefit from a social worker asking in assessment if she has a religious or spiritual community she is connected to and would like to seek help from. Given that a participant in this study reported having to go to a different mosque to avoid people she knew, practitioners could also ask if the client would like to be connected to a local religious community if she had to leave a former one behind. 
While findings indicate that faith communities are important in the lives of Black Muslim women, the specialized knowledge and skills that practitioners and other domestic violence advocates possess about recognizing signs of domestic violence, where people can seek help, and the multiple ways in which experiencing violence can shape mental health and wellness should not be discounted. While practitioners should seek to understand the needs and perspectives of different religious groups, we should also seek out opportunities to collaborate with faith institutions and organizations who are trying to address domestic violence in their communities. Prevention efforts targeted toward training religious leaders who are often first-responders to domestic violence in the Muslim community is especially needed, and this is an area in which those working in agency settings conducting outreach could build collaboration. This education has the potential to improve the outcome of women's religious help-seeking strategies. In the American Muslim community, organizations like the Peaceful Families Project offer trainings to leaders and community members about domestic violence. However, I did not identify any studies on these community interventions. Research that examines the effectiveness of such efforts in changing perceptions and responses of Muslim religious and community leaders is needed to understand how to either refine or spread such efforts to a wider audience.

This study also has additional implications for research. Within this small sample, women reported using religion and spirituality in different ways, and further investigation is needed to understand these differences in strategies, motivations for such strategies, and outcomes. Findings also reflect the connection between participants' identity as Muslims and its intersection with their identity as women; participants, explicitly and implicitly, spoke to their motivations and outcomes for religious and spiritual coping in light of being Muslim women. For example, Asiya and Latifah identified that while some leaders were supportive in addressing domestic violence, they also received messages that they should stay or have patience.; specifically, Latifah was told to stay in the relationship and focus on her children. Jamilah also spoke to her role as being good to her Muslim brother, which was inherently rooted in her role as his wife and being fearful of "outing" his violence to the larger community. While the exploration of gender and religious identity were limited to the questions and aim of this article, further research is needed that examines how identity and the diverse conceptualizations of identity shape women's coping. Specifically, future research should examine conceptualizations of "womanhood" and how this intersects with religious identity to shape how women view their options, how they respond, and their outcomes. 


\section{References}

Abu-Ras, W. M. (2003). Barriers to services for Arab immigrant battered women in a Detroit suburb. Journal of Social Work Research And Evaluation, 4, 49-66.

Akinsulure-Smith, A.M., Chu, T., Keatley, E., \& Rasmussen, A. (2013). Intimate partner violence among West African immigrants. Journal of Aggression, Maltreatment, \& Trauma, 22(2), 109-126. https://doi.org/10.1080/10926771.2013.719592

Alkhateeb, M. B., \& Abugideiri, S. E. (2007). Change from within: Diverse perspectives on domestic violence in Muslim communities. Great Falls, VA: Peaceful Families Project.

Al-Khateeb, S. (1999). Ending domestic violence in Muslim families. Journal of Religion \& Abuse, 1, 49-59. https://doi.org/10.1300/J154v01n04_04

Adam, N. M., \& Schewe, P. A. (2007). A multilevel framework exploring domestic violence against immigrant Indian and Pakistani women in the United States. Journal of Muslim Mental Health, 2(1), 5-20. https://doi.org/10.1080/15564900701238468

Auerbach, C. F., \& Silverstein, L. B. (2003). Qualitative data: An introduction to coding and analysis. New York: NYU Press.

Black, M.C., Basile, K.C., Breiding, M.J., Smith, S.G., Walters, M.L., Merrick, M.T., ... Stevens, M.R. (2011). The national intimate partner and sexual violence survey: 2010 summary report. Atlanta, GA: National Center for Injury Prevention and Control, Centers for Disease Control and Prevention.

Centers for Disease Control and Prevention. (2014, September 8). NISVS infographic. Retrieved from http://www.cdc.gov/violenceprevention/nisvs/infographic.html

Charmaz, K. (2006). Constructing grounded theory: A practical guide through qualitative analysis. London: Pine Forge Press.

Finn, J. (1985). The stresses and coping behavior of battered women. Social Casework: The Journal of Contemporary Social Work, 341-349. https://doi. org/10.1177/104438948506600604

Fowler, D. N., Faulkner, M., Learman, J., \& Runnels, R. (2011). The influence of spirituality on service utilization and satisfaction for women residing in a domestic violence shelter. Violence Against Women, 17(10), 1244-1259. https://doi. org/10.1177/1077801211424480

Gillum, T. L. (2008). Community response and needs of African American female survivors of domestic violence. Journal of Interpersonal Violence, 23(1), 39-57. https:// doi.org/10.1177/0886260507307650

Gillum, T. L., Sullivan, C. M., \& Bybee, D. I. (2006). The importance of spirituality in the lives of domestic violence survivors. Violence Against Women, 12(3), 240-250. https://doi.org/10.1177/1077801206286224

Goodman, L., Dutton, M. A., Weinfurt, K., \& Cook, S. (2003). The Intimate Partner Violence Strategies Index Development and Application. Violence Against Women, 9(2), 163-186. https://doi.org/10.1177/1077801202239004

Goodman, L. A., Smyth, K. F., Borges, A. M., \& Singer, R. (2009). When Crises Collide How Intimate Partner Violence and Poverty Intersect to Shape Women's Mental Health and Coping?. Trauma, Violence, \& Abuse, 10(4), 306-329. https://doi. org/10.1177/1524838009339754

Drumm, R. D., Thayer, J., Cooper, L. L., Mayer, S., Foster, T., Gadd, H., \& Brayak, K. (2017). Clergy training for effective response to intimate partner violence disclosure: Immediate and long-term benefits. Journal of Religion \& Spirituality in Social Work: Social Thought, 1-17. https://doi.org/10.1080/15426432.2017.1363011 
Hassouneh-Phillips D. (2003). Strength and vulnerability: Spirituality in abused American Muslim women's lives. Issues in Mental Health Nursing, 24(681-694). https:// doi.org/10.1080/01612840305324

Hassouneh-Phillips, D. (2001a). American Muslim women's experiences of leaving abusive relationships. Health Care for Women International, 22(4), 415-432. Retrieved from http://search.ebscohost.com/login.aspx?direct=true\&db=rzh\&AN= 2001097096\&site=ehost-live. https://doi.org/10.1080/07399330119163

Hassouneh-Phillips, D. (2001b). Polygamy and wife abuse: A Qualitative study of Muslim women in America. Health Care for Women International, 22(8), 735-748. https://doi.org/10.1080/073993301753339951

Hassouneh-Phillips, D. (2001c). "Marriage is half of faith and the rest is fear Allah": Marriage and spousal abuse among American Muslims. Violence Against Women, 7(8), 927-946. https://doi.org/10.1177/10778010122182839

Hennink, M., Hutter, I., \& Bailey (2011). Qualitative research methods. Thousand Oaks, CA: Sage.

Hodges, T. A., \& Cabanilla, A. S. (2011). Factors that impact help-seeking among battered back women: Application of critical and survivor theories. Journal Of Cultural Diversity, 18(4), 120-125.

Lindhorst, T., Nurius, P., \& Macy, R. J. (2005). Contextualized assessment with battered women: Strategic safety planning to cope with multiple harms. Journal of Social Work Education, 41(2), 331-352. https://doi.org/10.5175/JSWE.2005.200200261

Miles, M. B., Huberman, A. M., \& Saldaña, J. (2014). Qualitative data analysis: A methods sourcebook (3rd ed.) SAGE Publications, Incorporated.

Mitchell, M. D., Hargrove, G. L., Collins, M. H., Thompson, M. P., Reddick, T. L., \& Kaslow, N. J. (2006). Coping variables that mediate the relation between intimate partner violence and mental health outcomes among low-income, African American women. Journal of Clinical Psychology, 62(12), 1503-1520. https://doi. org/10.1002/jclp.20305

Latta, R. E., \& Goodman, L. A. (2005). Considering the interplay of cultural context and service provision in intimate partner violence: The case of Haitian immigrant women. Violence Against Women, 11(11), 1441-1464. https://doi. org/10.1177/1077801205280273

Nash, S. T. (2005). Through Black eyes African American women's constructions of their experiences with intimate male partner violence. Violence Against Women, 11(11), 1420-1440. https://doi.org/10.1177/1077801205280272

Oktay, J. S. (2012). Grounded theory. Oxford University Press. https://doi.org/10.1093/ acprof:oso/9780199753697.001.0001

Potter, H. (2007). Battered Black women's use of religious services and spirituality for assistance in leaving abusive relationships. Violence Against Women, 13(3), 262284. https://doi.org/10.1177/1077801206297438

Ting, L. (2010). Out of Africa: Coping strategies of African immigrant survivors of intimate partner violence. Health Care for Women International, 31(4), 345-364. https://doi.org/10.1080/07399330903348741

Tufford, L., \& Newman, P. (2012). Bracketing in qualitative research. Qualitative Social Work, 11(1), 80-96. https://doi.org/10.1177/1473325010368316

Waldrop, A. E., \& Resick, P. A. (2004). Coping among adult female victims of domestic violence. Journal of Family Violence, 19(5), 291-302. https://doi.org/10.1023/ B:JOFV.0000042079.91846.68

Watlington, C. G., \& Murphy, C. M. (2006). The roles of religion and spirituality among 
African American survivors of domestic violence. Journal of Clinical Psychology, 62(7), 837-857. https://doi.org/10.1002/jclp.20268

Yick, A. G. (2008). A metasynthesis of qualitative findings on the role of spirituality and religiosity among culturally diverse domestic violence survivors. Qualitative Health Research, 18(9), 1289-1306. https://doi.org/10.1177/1049732308321772

Younis, M. (2009). Muslim Americans exemplify diversity, potential. Retrieved from http://www.gallup.com/poll/116260/Muslim-Americans-Exemplify-DiversityPotential.aspx

\section{Glossary}

Allah - Arabic name for God $\operatorname{Ayah}(\mathrm{t})$ - Verse(s) of Qur'an

Cleric ${ }^{*}$ An English term used to refer to those in the Muslim community who are seen as religious leaders.

Dua - Supplication

Imam $^{*}$ - someone who leads prayer, but it is also used to mean a person who leads a mosque, which is a Muslim house of worship.

Jumah - Congregational Friday prayer

Masjid - Mosque

Qadr - Destiny

Qur'an - The Islamic holy book that was revealed by God through Angel

Gabriel to the Prophet Muhammad (peace and blessings be upon him

(PBUH)). Muslims believe the Qur'an to be the final reveled book of God. Sabr - Arabic work for patience

Tafseer - Exegesis of religious text

${ }^{\star}$ While these terms have slightly different meanings, they all are grouped under the umbrella of "religious leaders" in the text as those who hold such titles play leadership roles in Muslim communities. 